\title{
Transfection of Antisense Oligonucleotides Mediated by Cationic Vesicles Based on Non-Ionic Surfactant and Polycations Bearing Quaternary Ammonium Moieties
}

\author{
Judith Mayr ${ }^{1}$, Santiago Grijalvo ${ }^{2,3}$, Jürgen Bachl ${ }^{1}$, Ramon Pons ${ }^{2}$, Ramon Eritja ${ }^{2,3, *}$ \\ and David Díaz Díaz ${ }^{1,2, *}$ \\ 1 Institut für Organische Chemie, Universität Regensburg, Universitätsstr. 31, Regensburg 93053, Germany; \\ judith.mayr@chemie.uni-regensburg.de (J.M.); bachl_j@web.de (J.B.) \\ 2 Institute of Advanced Chemistry of Catalonia-Spanish National Research Council (IQAC-CSIC), \\ Jordi Girona 18-26, Barcelona 08034, Spain; sgrgma@cid.csic.es (S.G.); ramon.pons@iqac.csic.es (R.P.) \\ 3 Networking Centre in Bioengineering, Biomaterials and Nanomedicine (CIBER-BBN), Jordi Girona 18-26, \\ Barcelona 08034, Spain \\ * Correspondence: ramon.eritja@iqac.csic.es (R.E.); david.diaz@chemie.uni-regensburg.de (D.D.D.); \\ Tel.: +34-934006145 (R.E.); +49-941-943-4373 (D.D.D.); Fax: +49-941-943-4121 (D.D.D.)
}

Academic Editor: Andreas Taubert

Received: 15 March 2017; Accepted: 22 May 2017; Published: 26 May 2017

\begin{abstract}
Three different ionene polymers with varying quaternary ammonium moieties were used as a proof of concept for the formulation of antisense oligonucleotides, which are capable of inhibiting Renilla luciferase messenger ribonucleic acid (mRNA). Cationic vesicles, consisting of cationic polymer, antisense oligonucleotide $(L u c)$ and non-ionic surfactant polysorbate 80 , were investigated regarding their $\zeta$ potential, cytotoxicity and transfection efficiency. Deoxyribonucleic acid- (DNA) forming complexes in the presence of cationic vesicles were also investigated in terms of small-angle X-ray scattering (SAXS). The studied cationic vesicles showed very little, if any, toxicity against HeLa cells. Transfection abilities proved to vary strongly depending on the present quaternary ammonium moiety.
\end{abstract}

Keywords: antisense oligonucleotide; cationic polymers; cationic vesicles; ionenes; transfection; polycations; polyplexes; quaternary ammonium

\section{Introduction}

The last decades have witnessed a growing interest in the use of synthetic oligonucleotides for the inhibition of gene expression [1] as an alternative to the classical small molecule drugs to treat diseases. Examples for such oligonucleotides are antisense oligonucleotides, short interfering RNAs (siRNAs) [2], aptamers [3], DNA/RNAzymes and antisense-induced exon skipping [4,5]. In order to achieve the desired inhibition some obstacles must be solved. The first problem to solve is the high sensitivity of oligonucleotides towards degradation by serum nucleases. This has been partially solved by the use of chemical modifications of the oligonucleotides at the sugar ring and/or at the phosphate backbone in order to increase their biostability [6,7]. Cellular uptake of polyanionic oligonucleotides across the negatively charged cell membrane constitutes another problem. Although it has been shown that viral vectors are highly efficient for the transfection of plasmid DNA, there are still concerns about immunogenicity or recombination of oncogenes. Several alternatives for viral transfection methods have been developed including formulations as a very fast and simple method [8]. 
In 1987, Felgner and co-workers reported the first transfection experiment. They used the cationic lipid $N$-[1-(2,3-dioleyloxy)propyl]- $N, N, N$-trimethylammonium (DOTMA) for carrying out an efficient DNA transfection protocol [9]. Since this, a huge variety of cationic lipids for formulation of oligonucleotides have been described [10,11]. Even though they comprise promising tools for nucleic acid delivery there are several aspects to be considered. Cationic lipids have the tendency to interact with plasma proteins, which has a detrimental effect on transfection efficiency [12]. In addition, high positive net charge of the formulation can cause toxicity. Therefore a demand for new formulations is still present. One alternative to cationic lipids is the use of formulations based on cationic polymers and non-ionic surfactant agents to fine-tune the net charge. Cationic polymers are able to interact with DNA and RNA molecules with high efficiency and thus generate complexes with a relatively small size. This particularity makes cationic polymers useful non-viral carriers for improving gene transfection efficiency [12,13]. Although poly(ethylenimine) (PEI) and poly(L-lysine) (PLL) are the most well-known and used polymers for gene therapy, the synthesis and efficiency of novel cationic polymers to interact with nucleic acids in order to mediate cellular uptake have been recently reviewed $[13,14]$.

Ionenes are synthetic polycations with quaternary ammonium functions, which are distributed along the backbone $[15,16]$. In general, they can be synthesized by (a) self-polyaddition of aminoalkyl halides, (b) Menshutkin reaction between bis-tertiary amines and activated dihalide compounds or (c) via cationic functionalization of precursor polymers $[17,18]$. Inspired by our results which described the self-assembly properties of 1,4-diazabicyclo[2.2.2] octane (DABCO) derived ionene [19] as well as dye uptake [20] and phase-transfer catalysis [21], we decided to take advantage of the positively charged diammonium moieties present in ionene structures as cationic monomers to favor the electrostatic interaction process with nucleic acids [22-25]. In this work we have prepared surfactant-ionene formulations with a series of ionenes made of $N, N^{\prime}$-(o-phenylene)dibenzamide (1) and $\alpha, \omega$-tertiary diamines (Figure 1 ) with the aim to further study the DNA complexation in terms of zeta potential, small-angle X-ray scattering (SAXS) and effect of transfection efficiency potency in antisense technology [1] by studying the ability of the polyplexes depending on the linker length and flexibility of the polymers to inhibit the Renilla luciferase gene. As mentioned above, the use of a non-ionic surfactant in the formulation (Tween 80 ) aims to avoid interactions with plasma proteins [12] and cell toxicity observed for cationic lipids. Our findings showed that the cationic ionene polymers formulated with a non-ionic surfactant were not toxic and were able to deliver antisense oligonucleotides into cells, thereby inhibiting the luciferase expression with promising efficiencies. These results open new insights on the design of novel ionene-based non-viral carriers for nucleic acids.

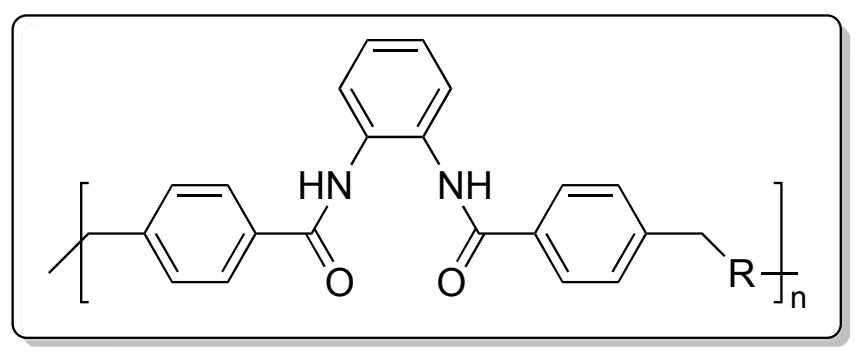

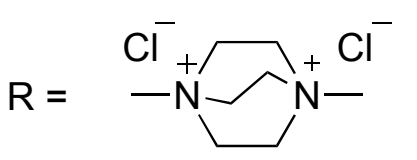

DABCO-ionene

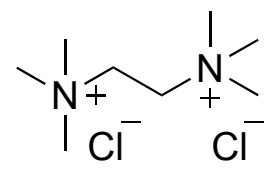

$\mathrm{C}_{2}$-ionene

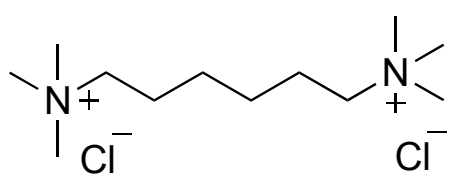

$\mathrm{C}_{6}$-ionene

Figure 1. Structures of ionene polymers used in this study with charged diammonium moieties with different structures and chain length. 


\section{Results and Discussion}

\subsection{Size and $\zeta$-Potential Measurements}

Cationic vesicles containing the respective ionene polymer and polysorbate 80 as a non-ionic surfactant agent were prepared by the thin-film hydration method in $20 \mathrm{mM}$ of 4-(2-hydroxyethyl)-1-piperazineethanesulfonic acid; HEPES (pH 7.4) buffer solution. A fixed amount of an antisense oligonucleotide $(0.5 \mu \mathrm{M}, L u c)$ was used to obtain a series of polyplexes at several $\mathrm{N} / \mathrm{P}$ ratios (ratio of nitrogen of polymer to phosphate of DNA) that ranged from 0.05 to 6 . Finally, the surface charge was measured in order to determine the overall charge of the preformed ionene polyplexes in solution.

As depicted in Figure 2, a transition from negative to positive values was clearly observed with an increase of the ionene concentration of the prepared cationic vesicle formulations. This change suggested the evidence of electrostatic interactions among negatively charged oligonucleotides and positively charged vesicles, which led to the formation of the expected ionene-based polyplexes. Interestingly, we noticed that this transition was different depending on the formulation used. Thus, in case of $\mathrm{DABCO}$-ionene the formulations reached a positive net charge at $\mathrm{N} / \mathrm{P}$ ratios $\geq 1.5$; whereas for $C_{2}$ - and $C_{6}$-ionene was around $\geq 0.5,1$ and 4 , respectively. All formulations reached a plateau when the surface charge density was compensated by an increase in the number of cationic polymer chains in the three systems ( $\mathrm{N} / \mathrm{P}$ ratio of 2,4 and 6$)$.
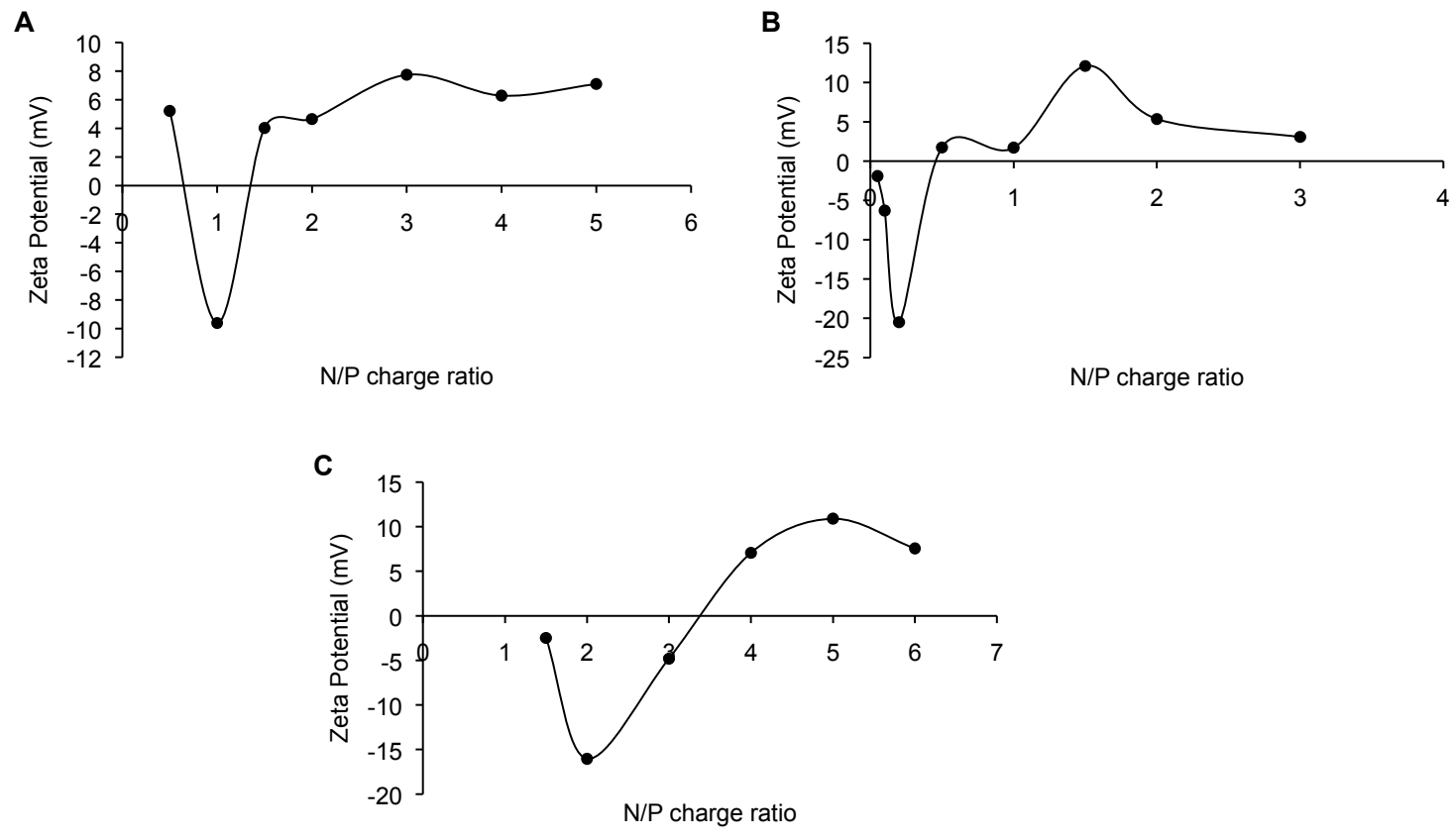

Figure 2. $\zeta$ potential of polyplexes at several N/P charge ratios derived from ionene polymers, antisense oligonucleotide and polysorbate 80 . (A) DABCO-ionene; (B) $\mathrm{C}_{2}$-ionene; (C) $\mathrm{C}_{6}$-ionene.

Surprisingly, we observed similar trends in the behavior of the systems when ionene formulations were added at lower N/P ratios. In particular, an initial decrease in the charge of the complexes was detected upon the addition of the cationic polymers, followed by a charge increase as described before. This initial decrease in the charge ratio was also observed and described with other families of cationic polymers, such as DNA-PEI complexes [26]. Similarly, the presence of initial amounts of cationic polymers in the three systems may result in varying the degree of the folding of DNA molecules by decreasing the amount of free DNA, therefore leading to an increase in the concentration of the negative charge. This effect was primarily observed when the first ionene-based polymers were added to these three systems. 


\subsection{SAXS Measurements}

To further investigate the structural information of our preformed ionene polyplexes, solutions of DNA from salmon testes in $20 \mathrm{mM}$ of HEPES ( $\mathrm{pH}$ 7.4) were put in contact with two representative ionene-based vesicle formulations $\left(\mathrm{C}_{2}\right.$ - and $\mathrm{C}_{6}$-ionene). The expected viscous complexes were formed, separated from the excess solution and washed with deionized water. The first attempts to visualize the scattered X-ray intensities were unsuccessful because the scattering signal was too weak for both complexes (data not shown). It is well known that DNA can be compacted by cationic surfactants forming lipoplexes, which can then co-precipitate at high concentrations to form gels with strong mechanical properties. When a drop of a concentrated DNA solution is put in contact with a concentrated cationic surfactant solution, macroscopic films can be obtained that surround the droplet. Interestingly, these films are quite consistent as they can be cut and opened. Furthermore, the films can be also dried and rehydrated, preserving their main structural properties as observed by SAXS [27]. Thus, to get better resolution and enhance the signal spectra, the resultant two complexes were further concentrated by evaporation. This process significantly showed the presence of one peak, which could be assigned to the pre-formed DNA complexes with $\mathrm{C}_{2}$ - and $\mathrm{C}_{6}$-ionene, respectively.

As illustrated in Figure 3A, scattered X-ray intensities of the two ionene complexes showed the presence of single peaks in which their position did not differ significantly among each other $(q=2.402$ and $2.306 \mathrm{~nm}^{-1}$ for polyplexes based on $\mathrm{C}_{2}$ - and $\mathrm{C}_{6}$-ionene, respectively). Disappointingly, we were not able to detect the presence of a second and third peak throughout the spectra, which might confirm a hexagonal packing of our pre-formed complexes. Additionally, the scattering pattern for the DNA from salmon testes (without forming complexes) was also included in the spectra for reference as a control. However, if we assume hexagonal symmetry as observed in lipoplexes [28], the distance calculated between the centers of the cylinders is $3.0 \mathrm{~nm}$ for $\mathrm{C}_{2}$-ionene and $3.1 \mathrm{~nm}$ for $\mathrm{C}_{6}$-ionene. By comparing these results with the DNA complexes made using other kinds of surfactant agents, we see that both ionene complexes are much more compact. For example, the observed distances between cylinders were between 4.2 and $4.7 \mathrm{~nm}$ in the case of several lipo-amino acid derivatives whereas the distance for cetyl trimethylamonium bromide (CTAB) and myristyltrimethyl ammonium bromide (MTAB) were 6.5 and $5.68 \mathrm{~nm}$, respectively [29]). If we tentatively compare these distances with the dimensions of a DNA double helix (diameter between 2.2 and $2.6 \mathrm{~nm}$ [30]), it seems that the structure of ionene-based complex might pack in a different way. Taking into consideration that DNA chains can form hexagonal structures intertwined with cationic lipid cylindrical micelles, the observed distances in the case of ionene complexes suggest diameters of 1.2 and $1.4 \mathrm{~nm}$ for $\mathrm{C}_{2}$ - and $\mathrm{C}_{6}$-ionene cylinders, respectively, with a 2:1 hexagonal. These diameters seem reasonable for these molecules.

Finding that SAXS measurements showed polyplex structures formed by the formulation based on $C_{2}$ - and $C_{6}$-ionene and DNA salmon testes were similar, the polyplex made of the $C_{6}: L u c$ oligonucleotide was chosen as a representative compound to carry out the corresponding dynamic light scattering (DLS) measurements. As illustrated in Figure 3B, polyplexes were formed and showed an average diameter size of $320 \pm 5 \mathrm{~nm}$ with good degree of dispersity (0.3). Additionally, polyplexes based on $\mathrm{C}_{6}$-ionene were characterized by a cryo-scanning electron microscopy (cryo-SEM) (Figure 3C). The cryo-SEM analysis revealed spherical morphologies of the particles with similar average sizes $(340 \mathrm{~nm})$ than those achieved through the use of DLS, as previously described. These results show the appropriateness of the use of $\mathrm{C}_{6}$-ionene polymer as a non-viral vehicle for nucleic acids (e.g., phosphorothioate and siRNA oligonucleotides). 
A

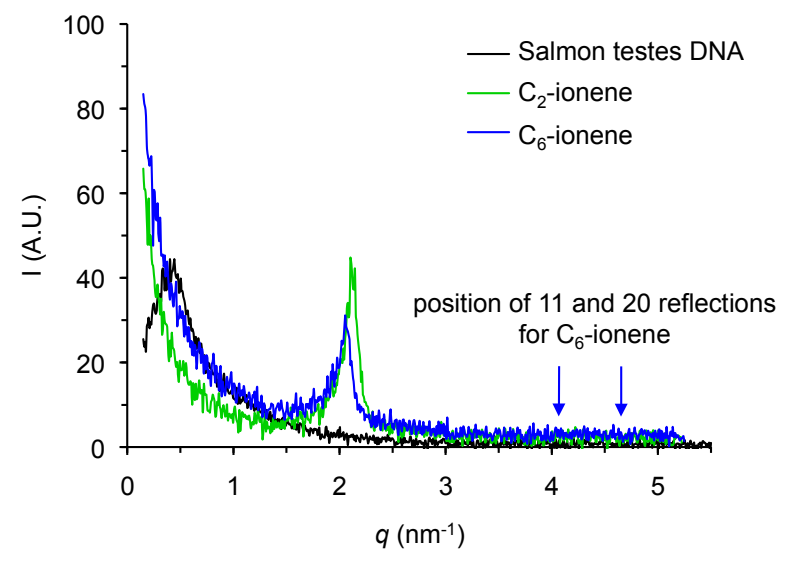

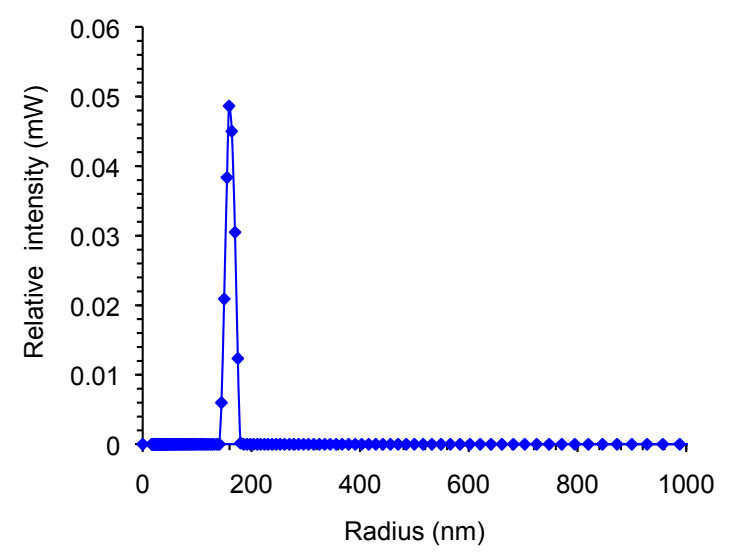

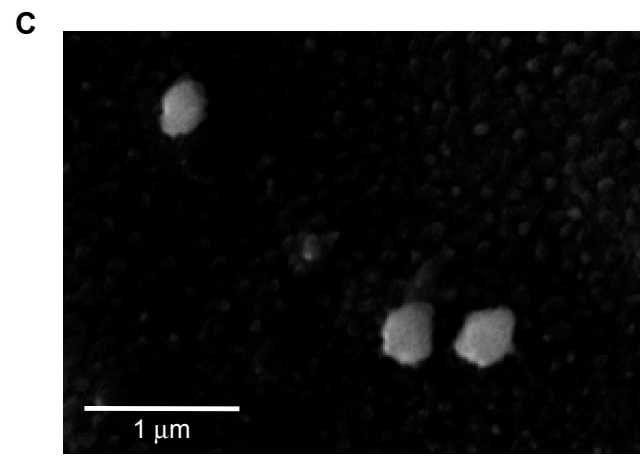

Figure 3. (A) Scattered X-ray intensity as a function of scattering vector $q$ at $25{ }^{\circ} \mathrm{C}$. The complex for $\mathrm{C}_{2}$-ionene (green) and $\mathrm{C}_{6}$-ionene (blue) are shown together. The scattering pattern produced by the salmon testes DNA (black) is also included as a control. The expected positions of second and third reflexions for hexagonal packing are shown for $\mathrm{C}_{6}$-ionene as arrows; (B) Representative dynamic light scattering DLS measurement of polyplex made of $\mathrm{C}_{6}: L u c$ oligonucleotide; (C) Representative cryo-scanning electron microscopy image of polyplexes based on $\mathrm{C}_{6}$-ionene.

\subsection{Cytotoxicity Assay}

Prior to transfection experiments, the cytotoxicity of polyplexes (containing the antisense oligonucleotide, $L u c$ ) derived from the different ionenes was tested on the HeLa cells. Three concentrations were evaluated $(60,120$ and $300 \mathrm{nM})$ with respect to the $L u c$ oligonucleotide at N/P ratios of 2, 4 and 6, respectively. As a control, the effect on the HeLa cells viability of the three cationic vesicle formulations (DABCO-ionene, $\mathrm{C}_{2}$-ionene and $\mathrm{C}_{6}$-ionene; mock) without forming complexes with Luc, was also tested at $0.6,1.20$ and $3.0 \mu \mathrm{M}$ (concentrations that were used for the preparation of the polyplexes). Cells were incubated with the respective formulations at $37^{\circ} \mathrm{C}$ for $24 \mathrm{~h}$ and normalized viabilities of treated cells with regard to untreated cells were measured by using a tetrazolium-based colorimetric (MTT) assay [31].

As displayed in Figure 4, vesicle formulations that did not contain the Luc oligonucleotide showed no cytotoxicity at the three concentrations tested (cellular viabilities $>90 \%$ ). Also, polyplexes containing $60 \mathrm{nM}$ of Luc proved to be harmless to the HeLa cells at N/P ratios of 2, 4 and 6, respectively. With respect to $\mathrm{Luc}$, the formulations derived from $\mathrm{DABCO}$ - and $\mathrm{C}_{2}$-ionene still showed perfect nontoxic behavior at concentrations of $300 \mathrm{nM}$. However, those derived from $\mathrm{C}_{6}$-ionene based formulations showed a clear decrease in cell viability with rising $\mathrm{N} / \mathrm{P}$ ratios (from $\mathrm{N} / \mathrm{P}=4: 78 \%$ to $\mathrm{N} / \mathrm{P}=6: 46 \%$ ). Additionally, we also evaluated the toxicity caused by the preformed lipoplexes based on lipofectamine and the Luc oligonucleotide as controls. As displayed in Figure S1 (Supporting Information), polyplexes obtained at $60 \mathrm{nM}$ of the Luc oligonucleotide showed low toxicity levels whereas the presence of polyplexes obtained at 120 and $300 \mathrm{nM}$ of the Luc oligonucleotide was 
detrimental to cellular viability (55\% in both cases). This result confirmed the data obtained by microscopy in which changes in the morphology of the cells were observed after treatment with lipoplexes at $300 \mathrm{nM}$ (Figure S2).

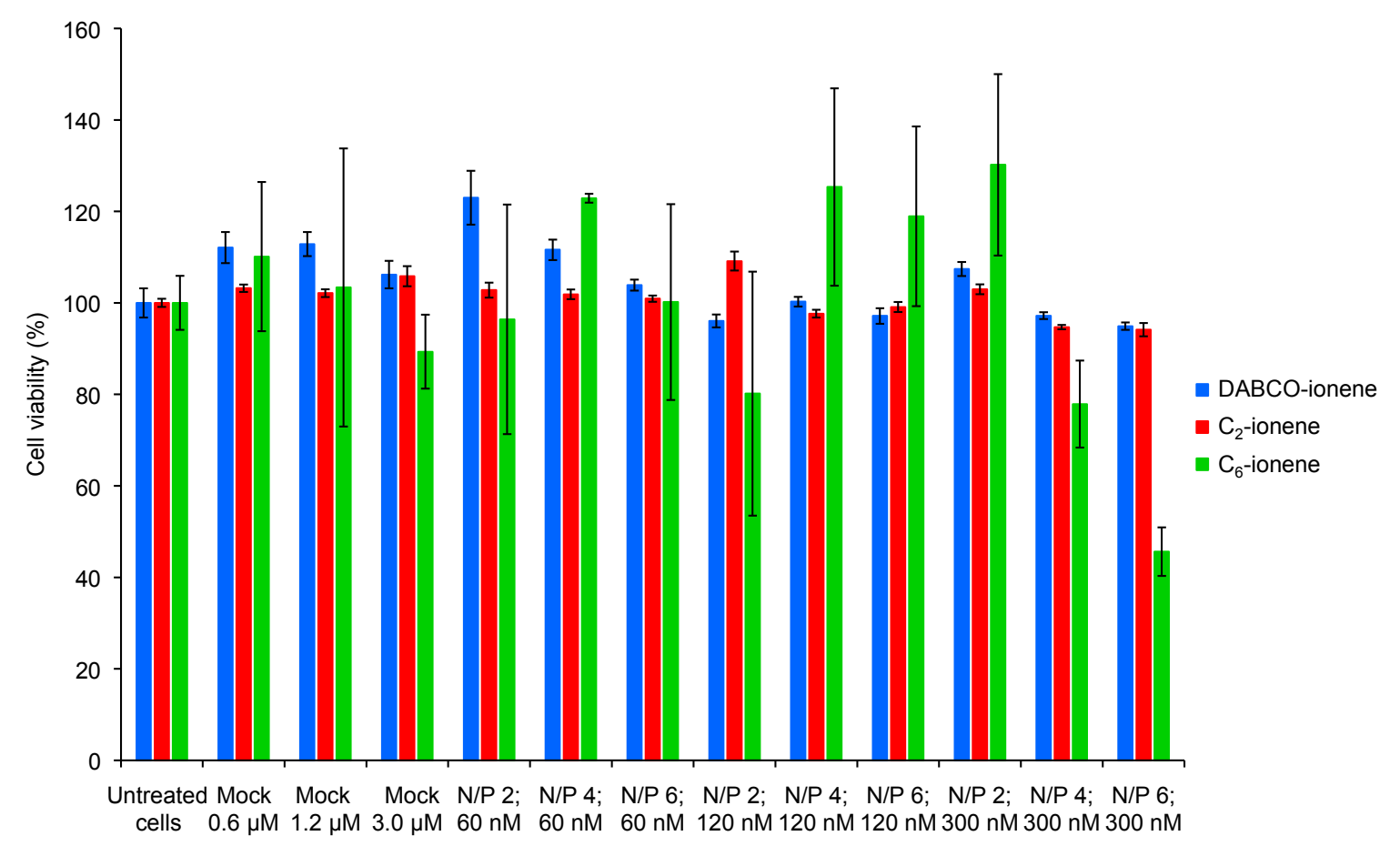

Figure 4. Normalized cell viability of polyplexes derived from ionenes, antisense oligonucleotide and polysorbate 80 . Toxicity of cationic vesicles without forming complexes was also tested. Polyplexes were tested at 60,120 and $300 \mathrm{nM}$ (concentration of $L u c$ oligonucleotide) with N/P ratios of 2, 4 and 6. Ionene-based polymers (DABCO, $\mathrm{C}_{2}$ and $\mathrm{C}_{6}$, respectively) without forming polyplexes were tested at $0.6,1.2$ and $300 \mu \mathrm{M}$, respectively). DABCO-ionene = blue color, $\mathrm{C}_{2}$-ionene = red color, $\mathrm{C}_{6}$-ionene $=$ green color. Each value represents the mean of at least 5 measurements.

\subsection{Transfection}

The described ionene-based formulations (DABCO-, $\mathrm{C}_{2}$ - and $\mathrm{C}_{6}$-ionene) containing an antisense oligonucleotide $(L u c)$, a 17-mer complementary to the mRNA Renilla luciferase gene, have been tested regarding their ability of silencing luciferase activity (Figure 5). Generally, cationic particles are prone to interact with negatively charged proteins which may initiate aggregation processes leading to increasing particle sizes that may abolish the effectiveness of gene transfection [32]. To avoid this undesirable effect, initial transfection experiments mediated by ionene formulations were evaluated in the absence of serum proteins (Figure 5A). Thus, cationic polyplexes at concentrations of $120 \mathrm{nM}$ with respect to $L u c$ oligonucleotide at N/P ratios of 2 and 4 (N/P ratio of 6 was dismissed according to MTT data) were prepared.

Interestingly, two factors influenced the transfection process: the ionene structure and the relationship between ionene molar and charge ratio. According to Figure 5A, the use of the DABCO ionene-based formulation was detrimental in the transfection at the two N/P ratios tested, possibly due to the rigid linker which might have a detrimental effect on complex formation with oligonucleotides and therefore a negative effect on mediating nucleic acid delivery. However, moderate gene silencing activities were obtained with cationic formulations at a N/P ratio of 4 , under serum-free conditions at $120 \mathrm{nM}$ with knockdown values of $40 \%$ and $27 \%$ for $\mathrm{C}_{2}$ - and $\mathrm{C}_{6}$-ionene, respectively which inhibited luciferase production. This silencing activity, though modest, might come from the release and discharge of the $L u c$ oligonucleotide from endosomes, most likely by protonation mechanisms [33]. 
A

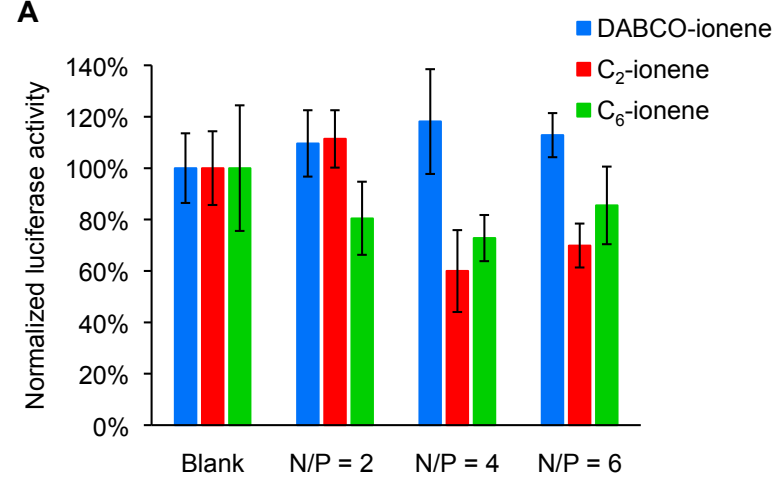

B

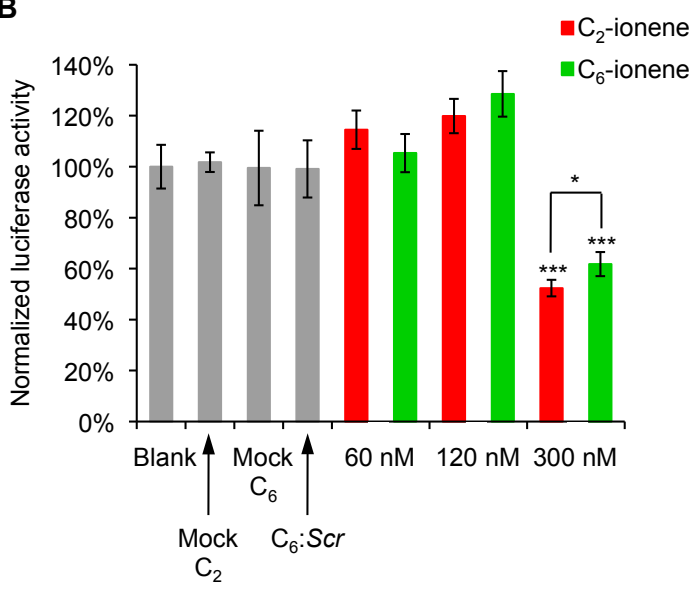

Figure 5. Normalized gene-specific silencing activities targeting Renilla luciferase mRNA for polyplex formulations. (A) In the absence of fetal bovine serum (FBS), at different N/P ratios at $120 \mathrm{nM}$ and (B) in the presence of FBS at concentrations of 60,120 and $300 \mathrm{nM}$. Data are expressed as mean values of three replicates $( \pm \mathrm{SD}){ }^{*}$ and ${ }^{* * *}$ indicate $p<0.05$ and $p<0.001$, respectively.

As $\mathrm{C}_{2}-$ and $\mathrm{C}_{6}$-ionene formulations at a $\mathrm{N} / \mathrm{P}$ ratio of 4 showed the best transfection profile and lowest toxicity at $120 \mathrm{nM}$, they were used for investigating the gene-silencing abilities in the presence of 10\% fetal bovine serum (FBS) (Figure 5B) and at concentrations of 60, 120 and $300 \mathrm{nM}$ with respect to the $L u c$ oligonucleotide. According to the results, transfection efficiencies strongly depended upon the presence of the serum, which tended to interact eagerly with our two cationic polyplexes. This interaction resulted in decreasing the transfection efficiency of the formulations. Thus, while $\mathrm{C}_{2}$ - and $\mathrm{C}_{6}$-ionene polyplexes silenced the Renilla luciferase 40 (and $27 \%$ at $120 \mathrm{nM}$ in the absence of FBS), the presence of FBS was detrimental on inhibiting luciferase at the same concentration. Curiously, the values obtained for the two ionenes $\left(C_{2}\right.$ and $\left.C_{6}\right)$ at $120 \mathrm{nM}$ exceeded approximately $10-20 \%$ of the values obtained for untreated cells (blank) according to the dual-luciferase reporter assay. It is undeniable that these results confirm our ionene-based polyplexes were not able to impart cellular uptake and therefore inhibit luciferase production at $120 \mathrm{nM}$. However, we are unable to demonstrate whether there might have been undesirable interactions among the ionene-based polymers and the Renilla/Firefly luciferases at the aforementioned concentration. However, it is also noteworthy that this anomalous behavior was occasionally observed with other non-viral carriers, such as the proline-rich cell-penetrating peptides [34] and carbosilane dendrons [35], as vehicles to transport antisense oligonucleotides.

When the concentration of the $L u c$ oligonucleotide was increased up to $300 \mathrm{nM}$, both ionene formulations $\left(\mathrm{C}_{2}\right.$ - and $\mathrm{C}_{6}$-ionene) were able to promote gene delivery with similar and significant efficiencies ( $48 \%$ and $38 \%$ luciferase inhibition for $C_{2}$ - and $C_{6}$-ionene, respectively) ${ }^{* * *} p<0.001$ ). Interestingly, these silencing activities, though similar, were also found to be statistically significant in the case of $C_{2}$-ionene formulations when compared to $C_{6}$-ionene formulations ( ${ }^{*} p<0.05$ ). It seems that a medium-sized chain length of the linker has a beneficial effect on the transfection ability; perhaps the proper balance between rigidity and flexibility of the polymers must be found for optimal effects. Additionally, a scramble ( $\mathrm{Scr}$ ) oligonucleotide complexed with $\mathrm{C}_{6}$-ionene formulation at the same $\mathrm{N} / \mathrm{P}$ ratio of 4 together with $\mathrm{C}_{2}-$ and $\mathrm{C}_{6}$-ionene formulations without forming polyplexes (mock) were used as controls and did not produce any effect on luciferase inhibition, as expected. Finally, to determine the specificity of the gene transfection process, the $L u c$ and $S c r$ oligonucleotides $(60 \mathrm{nM})$ were formulated into liposomes as controls (in the presence of lipofectamine), obtaining similar inhibition results as previously reported [34] (Supporting Information; Figure S3). 


\section{Materials and Methods}

\subsection{Materials}

Polysorbate 80 (Tween 80), 3-(4,5-dimethylthiazol-2-yl)-2,5-diphenyltetrazolium bromide (MTT reagent), sodium salt of DNA from salmon testes (polymerization average degree of 2000 base pairs) and antisense oligonucleotide of sequence (5'-CGT TTC CTT TGT TCT GGA-3'; Luc) were purchased from Sigma-Aldrich (St. Louis, MO, United States) and used as received. A scramble sequence (5'-CTG TCT GAC GTT CTT TGT-3'; Scr) was synthesized in-house and purified by dimethoxyltrityl, DMT off-based protocols. Lipofectamine 2000 was purchased from Invitrogen (Carlsbad, CA, USA). Phosphate-buffered saline (PBS) buffer and Dulbecco's Modified Eagle's Medium (DMEM), which was supplemented with a 10\% heat-inactive fetal bovine serum (FBS) along with distilled water (DNAse/RNAse free) were purchased from Gibco (Waltham, MA, USA). Additional nuclease-free water was also prepared by using $0.1 \%$ of diethylpyrocarbonate (DEPC) to ensure the removal of RNase contamination, as well as autoclaved and filtered before using. Luciferase assay kits were purchased from Promega (Madison, WI, United States). Qiagen Giga plasmid purification kit was purchased from Qiagen (Hilden, Germany). Starting materials for polymer synthesis were purchased from Sigma Aldrich (St. Louis, MO, USA) or TCI (Zwijndrecht, Belgium). Luminiscence values were measured in a Promega Glomax Multidetection instrument (Madison, WI, USA). All ionene polymers were synthesized by step-growth polymerization following the two-step procedure previously described and showed the same spectroscopic data [19-21,36]. In short, the reaction of o-phenylenediamine with 4-(chloromethyl)benzoyl chloride in the presence of $\mathrm{Et}_{3} \mathrm{~N}^{\text {in }} \mathrm{CH}_{2} \mathrm{Cl}_{2}$ afforded the corresponding bis-benzamides in good yields (75-98\%). Subsequent copolymerization with equimolar amounts of the desired $\alpha, \omega$-diamine in dimethylformamide (DMF) at $80{ }^{\circ} \mathrm{C}$ provided white precipitates within 2-6 days. The precipitates were filtered, washed (with $\mathrm{DMF}, \mathrm{CH}_{3} \mathrm{CN}$ and $\mathrm{CH}_{2} \mathrm{Cl}_{2}$ ) and dried under vacuum to afford the ionenes in modest yields (43-80\%). Sufficient solubility for gel permeation chromatography (GPC) was achieved by exchanging the chloride anions by bis(trifluoromethanesulfonyl)amide (TFSA) anions using lithium bis(trifluoromethanesulfonyl)azanide (LiTFSA) in hot water. These ionenes.TFSA showed low degrees of polymerization $(n=7-14)$ and high dispersity values $(\bigoplus=2.1-3.1)$. Weight-average molecular weights, $M_{\mathrm{W}}(\mathrm{Da})$, for ionenes·TFSA: $8.1 \times 10^{3}$ (DABCO-ionene); $1.6 \times 10^{4}\left(\mathrm{C}_{2}\right.$-ionene $) ; 6.9 \times 10^{4}\left(\mathrm{C}_{6}\right.$-ionene $)$; number-average molecular weight, $M_{\mathrm{n}}(\mathrm{Da})$, for ionenes.TFSA: $3.9 \times 10^{3}$ (DABCO-ionene); $6.1 \times 10^{3}$ ( $\mathrm{C}_{2}$-ionene); $2.2 \times 10^{3}$ $\left(\mathrm{C}_{6}\right.$-ionene $)$.

\subsection{Preparation of Polyplexes}

Cationic vesicles were prepared by mixing ionenes (1-2 mg) and polysorbate 80 in a 1:1 $(n / n)$ molar ratio and dissolving/suspending those in MilliQ water $(1 \mathrm{~mL})$. Mixtures were dried in a speed vacuum at $45^{\circ} \mathrm{C}$ for $18 \mathrm{~h}$. The resulting film was rehydrated in $1 \mathrm{~mL}$ of sterile HEPES buffer $(20 \mathrm{mM}$; $\mathrm{pH}$ 7.4), incubated at $60{ }^{\circ} \mathrm{C}$ for $20 \mathrm{~min}$, sonicated for $3 \mathrm{~min}$ and filtered through a $13 \mathrm{~mm}$ nylon filter with $0.2 \mu \mathrm{m}$ pore width. Polyplexes were obtained by adding an oligonucleotide stock solution to the cationic vesicle solutions to give N/P ratios ([cationic amino groups] $]_{\text {ionene/[anionic phosphate }}$ groups $]_{\text {nucleic acid }}$ ) between 0.05 and 8 . The mixtures were vortexed, sonicated for $10 \mathrm{~s}$ and finally incubated at $37^{\circ} \mathrm{C}$ for $30 \mathrm{~min}$.

The synthesized ionene monomers each contained two terminal amine groups that were positively charged at physiological pH conditions (7.4). The antisense oligonucleotide (Luc oligonucleotide) contains 17 negative charges and the N/P ratio can be calculated by using Equation (1), as described elsewhere [37].

$$
\mathrm{N} / \mathrm{P} \text { ratio }=\frac{\text { number of moles of ionene monomer } \times 2}{\text { number of moles of Luc oligonucleotide } \times 17}
$$




\subsection{Zeta Potential}

The zeta potential values were obtained by laser Doppler velocimetry by using a Zetasizer Nano ZS (Malvern Instruments; Malvern, UK) equipped with a He-Ne red light laser $(\lambda=633 \mathrm{~nm})$. Polyplex solutions were measured at an oligonucleotide concentration of $0.5 \mu \mathrm{M}$ and N/P ratios from 0.05 to 6 at $25^{\circ} \mathrm{C}$. Samples $(50 \mu \mathrm{L})$ were diluted in $0.1 \mathrm{mM} \mathrm{NaCl}$ solution $(950 \mu \mathrm{L})$ and introduced into folded capillary cells. The Smoluchowski approximation was used to calculate the $\zeta$ potential values. Measurements were run in triplicate.

\subsection{Size Measurements}

The hydrodynamic diameter of polyplexes (cationic ionene/DNA complexes) was determined by a dynamic light scattering (DLS) spectrometer (LS Instruments, 3D-cross correlation multiple scattering) equipped with a He-Ne laser $(632.8 \mathrm{~nm})$. Measurements were carried out at a scattering angle of $90^{\circ}$, in triplicates at $25^{\circ} \mathrm{C}$ without sonication. The particle radii were calculated by fitting the first cumulant parameter.

\subsection{Small-Angle X-ray Scattering (SAXS) Measurements of Ionene Polyplexes}

Small-angle X-ray scattering measurements were recorded on S3-MICRO (Hecus X-ray system, GMBH, Graz, Austria) which was coupled to a GENIX-Fox 3D X-ray source (Xenox, Grenoble) and coupled with a 3D-focusing mirror, which produced a detector-focused X-ray beam with $\lambda=0.1542 \mathrm{~nm}$ $\mathrm{Cu} K_{\alpha}$-line (greater than $97 \%$ purity and less than $0.3 \%$ of $K_{\alpha}$ ). Transmitted scattering was measured by using a PSD 50 Hecus in the SAXS regime $\left(0.09 \mathrm{~nm}^{-1}<q<6 \mathrm{~nm}^{-1}\right)$ including Bragg peaks and diffuse scattering. Measurements were carried out at a constant temperature $\left(25^{\circ} \mathrm{C}\right)$ for $24 \mathrm{~h}$. Detector counting was accumulated for 20 min intervals; if no temporal variation was observed, several runs were summed up to reduce the noise of background level. A stock concentration of DNA from salmon testes in $20 \mathrm{mM}$ of HEPES ( $\mathrm{pH}$ 7.4) was properly mixed with a stock concentration of a surfactant-ionene formulation in $20 \mathrm{mM}$ of HEPES buffer at $37^{\circ} \mathrm{C}$ for $30 \mathrm{~min}$. The resultant polyplexes (DNA: ionene complexes) were isolated, dried and deposited in a glass capillary of $1 \mathrm{~mm}$ diameter with $10 \mu \mathrm{m}$ wall thickness. SAXS scattering curves were plotted as a function of the scattering vector modulus (Equation (2)) where $\theta$ is the scattering angle and $\lambda$ the incident radiation wavelength. A silver behenate sample was used in order to calibrate the system scattering vector.

$$
q=\frac{4 \pi}{\lambda} \sin \frac{\theta}{2}
$$

\subsection{Cryo-Scanning Electron Microscopy (cryo-SEM)}

Polyplexes made of an ionene- $\mathrm{C}_{6}$ based formulation and the $\mathrm{Luc}$ oligonucleotide were obtained at a N/P ratio of 4 . The resultant polyplexes were rapidly frozen in liquid nitrogen and cut with an equipped cold knife. Polyplexes were sputered with gold palladium, observed and processed by using a Hitachi S-3500N (Hitachi High-Technologies Corp., Tokyo, Japan) scanning electron microscope operated at $5 \mathrm{kV}$.

\subsection{Cytotoxicity Assay}

The adherent cell line HeLa (human carcinoma) was plated at a density of $5 \times 10^{3}$ cells/well (50\% confluency) on a 96-well plate in $200 \mu \mathrm{L}$ of Dulbecco's Modified Eagle's medium (DMEM), supplemented with $10 \%$ fetal bovine serum (FBS), in the absence of antibiotics. The HeLa cells were incubated at $37^{\circ} \mathrm{C}$ in a humidified atmosphere $\left(5 \% \mathrm{CO}_{2}\right)$ for $24 \mathrm{~h}$ to permit cell attachment. Then the medium was removed and replaced by fresh one to give a final concentration of $200 \mu \mathrm{L}$. Polyplexes and cationic vesicles were prepared as described above and added to the wells to give concentrations of 60,120 and $300 \mathrm{nM}$ and N/P ratios of 2, 4 and 6 . The mixture was incubated at $37^{\circ} \mathrm{C}$ for $18 \mathrm{~h}$, then the medium was removed and the wells were washed with PBS $(1 \times 200 \mu \mathrm{L})$. Fresh DMEM was 
added $(200 \mu \mathrm{L})$ and cells were incubated again at $37^{\circ} \mathrm{C}$ for $3 \mathrm{~h}$. MTT solution $(10 \mu \mathrm{L} ; 5 \mathrm{~g} / \mathrm{L}$ in PBS buffer) was added to each well and plates were stored at $37^{\circ} \mathrm{C}$ for further $2.5 \mathrm{~h}$. Then medium was removed, DMSO $(100 \mu \mathrm{L})$ was added and absorbance was measured at $570 \mathrm{~nm}$. Each measurement was performed with six replicates. Additionally, to evaluate the effect of lipofectamine in the HeLa cells, the Luc oligonucleotide was mixed at 60,120 and $300 \mathrm{nM}$, respectively at room temperature with lipofectamine, according to the manufacture's protocol. HeLa cells and the corresponding lipoplexes were incubated following the same experimental procedure as described before.

\subsection{Gene Transfection and Antisense Technology Studies}

\subsubsection{In the Absence of FBS}

The HeLa cells were regularly passaged to maintain exponential growth. Cells were seeded the day before at a density of $10^{5}$ cells /well on a 24-well plate, with each well in DMEM (supplemented with $10 \%$ FBS). Cells were incubated at $37{ }^{\circ} \mathrm{C}$ for $18 \mathrm{~h}$ in a humidified atmosphere $\left(5 \% \mathrm{CO}_{2}\right)$ to permit cell attachment. The medium was then replaced by fresh one $(500 \mu \mathrm{L})$. A solution containing firefly luciferase (pGL4) $(30 \mu \mathrm{L} ; 100 \mathrm{ng} / \mu \mathrm{L})$ and Renilla luciferase $(30 \mu \mathrm{L} ; 10 \mathrm{ng} / \mu \mathrm{L})$ in Opti-MEM ${ }^{\mathrm{TM}}$ $(90 \mu \mathrm{L})$ was combined to a solution containing Lipofectamine $2000(3.9 \mu \mathrm{L} ; 1 \mathrm{mg} / \mathrm{mL})$ in Opti-MEM ${ }^{\mathrm{TM}}$ $(146.4 \mu \mathrm{L})$. The resultant formulation was incubated for $10 \mathrm{~min}$ at room temperature. One hundred $\mu \mathrm{L}$ of this formulation was added to each well and the cells were incubated at $37^{\circ} \mathrm{C}$ for $6 \mathrm{~h}$. The medium was removed, the cells were washed with PBS $(2 \times 400 \mu \mathrm{L})$ and DMEM without FBS was added $(500 \mu \mathrm{L})$. Polyplexes were added $(100 \mu \mathrm{L})$ to give final oligonucleotide concentrations of $120 \mathrm{nM}$ and $\mathrm{N} / \mathrm{P}$ ratios of 2,4 and 6 and cells were incubated at $37^{\circ} \mathrm{C}$ for $24 \mathrm{~h}$. The medium was removed, the cells were washed with PBS $(1 \times 500 \mu \mathrm{L})$ and the cells were stored at $-20^{\circ} \mathrm{C}$ for $18 \mathrm{~h}$. After thawing the cells, $100 \mu \mathrm{L}$ of lysis buffer was added to each well. The plate was shaken at $480 \mathrm{rpm}$ at room temperature for $15 \mathrm{~min}$. Lysates $(25 \mu \mathrm{L})$ were transferred to a 96-well plate and luminescence was recorded after adding, alternatingly, Luciferase assay reagent $(25 \mu \mathrm{L})$ and Stop \& Glow reagent $(25 \mu \mathrm{L})$. Inhibition results generated by polyplex-based ionenes were expressed as normalized ratios between the reported luciferase (Renilla) and control luciferase (Firefly).

\subsubsection{In the Presence of FBS}

The HeLa cells were regularly passaged to maintain exponential growth. Cells were seeded the day before at a density of $10^{5}$ cells / well on a 24-well plate each well in DMEM supplemented with $10 \%$ FBS. The cells were incubated at $37^{\circ} \mathrm{C}$ for $18 \mathrm{~h}$. The Renilla and Firefly luciferases were transfected following the same procedure as described above. After $6 \mathrm{~h}$ of incubation at $37^{\circ} \mathrm{C}$, the medium was removed, cells were washed with PBS $(2 \times 400 \mu \mathrm{L})$, and DMEM supplemented with $10 \%$ FBS was added $(500 \mu \mathrm{L})$. Polyplexes were added to give a final N/P ratio of 4 and oligonucleotide concentrations of 60,120 and $300 \mathrm{nM}$. The cells were incubated at $37^{\circ} \mathrm{C}$ for $24 \mathrm{~h}$. The medium was removed, cells were washed with PBS $(1 \times 500 \mu \mathrm{L})$ and stored at $-20^{\circ} \mathrm{C}$ for $18 \mathrm{~h}$. After thawing the cells, $100 \mu \mathrm{L}$ of lysis buffer were added to each well. Luminiscence was measured following the same protocol as described before. Inhibition results generated by polyplex-based ionenes were expressed as normalized ratios between the reported luciferase (Renilla) and control luciferase (Firefly). Luc and Scr oligonucleotides at $60 \mathrm{nM}$ were formulated into liposomes (in the presence of lipofectamine) as positive and negative controls, respectively.

Statistical Analysis. Data were shown as mean \pm standard deviation (SD) and are the result of an average of three replicates. Statistical differences were determined by using Student's $t$-test and were considered significant when ${ }^{*} p<0.05$ and ${ }^{* * *} p<0.001$.

\section{Conclusions}

Cationic vesicles derived from ionene polymers with an alternating $\alpha, \omega$-tertiary diamine linker and the non-ionic surfactant polysorbate 80 were used to entrap oligonucleotide single strands which 
were complementary to Renilla luciferase mRNA. The zeta potential of the vesicle formulations at different $\mathrm{N} / \mathrm{P}$ ratios ([cationic amino groups] $]_{\text {ionene }} /$ [anionic phosphate groups $]_{\text {nucleic acid }}$ ) was measured to ensure a positive charge of the system. The MTT assay showed no toxicity for formulations derived from DABCO- and $\mathrm{C}_{2}$-ionene at several concentrations and $\mathrm{N} / \mathrm{P}$ ratios $(2,4$ and 6$)$ whereas $\mathrm{C}_{6}$-ionene showed critical cell viabilities at $300 \mathrm{nM}$ with a $\mathrm{N} / \mathrm{P}$ ratio of 6 ( $46 \%$ of cell viability). Transfection experiments of all cationic vesicle formulation were investigated by performing a luciferase activity assay at $120 \mathrm{nM}$ and N/P ratios of 2 and 4 in the absence of proteins. As a result, DABCO-ionene derived formulations showed no transfection ability at both $\mathrm{N} / \mathrm{P}$ ratios tested. The contrast for $\mathrm{C}_{2}$ - and $\mathrm{C}_{6}$-ionene derived formulations showed perfect non-toxic behavior, and the luciferase activity was reduced by 48 and $38 \%$ respectively, at a N/P ratio of 4 and Luc concentration of $300 \mathrm{nM}$. The use of this complete, harmless formulation at higher concentrations might be an interesting alternative to current transfection agents. Further structure-activity relationships need to be carried out in order to obtain optimized cationic ionene derivatives that are less susceptible to FBS proteins. In addition, further studies to determine the effect of the polymer topology (positional isomers) on the transfection efficiency are under way in our laboratories and the results will be reported in due course.

Supplementary Materials: Supplementary materials can be found at http://www.mdpi.com/1422-0067/18/6/ 1139/s1.

Acknowledgments: Financial support from Deutsche Forschungsgemeinschaft (DFG) (DI 1748/3-1; DI 1748/3-2) and Universität Regensburg is gratefully acknowledged. Part of this work was also supported by the Spanish Ministry of Education (Grant CTQ2014-52588-R), the Generalitat de Catalunya (2014/SGR/624) and the Instituto de Salud Carlos III (CB06_01_0019). Authors wish to thank the Nanostructured Liquid Characterization Unit (U12, CIBER-BBN Research Infrastructures, NANBIOSIS), especially, Susana Vílchez for her help with DLS and zeta potential measurements. NANBIOSIS is one of the 29 Singular Scientific Technological Infrastructures (ICTS) recently recognized by the Spanish Council for Science Policy, Technology and Innovation (MINECO). Authors also thank Jaume Caelles from IQAC SAXS-WAXS Service for SAXS measurements and José Manuel Fortuño from the Institute of Marine Sciences (ICM-CSIC) for the cryo-SEM observations. Judith Mayr thanks international PhD program at Universität Regensburg (iPUR) for funding a research internship in Barcelona, Spain. David Díaz Díaz thanks DFG for the Heisenberg Professorship Award.

Author Contributions: Judith Mayr and Jürgen Bachl synthesized the polymers. Judith Mayr and Santiago Grijalvo performed the rest of the experiments. Ramon Pons designed the SAXS experiments. David Díaz Díaz, Santiago Grijalvo and Ramon Eritja conceived and directed the project. All authors participated in writing the manuscript.

Conflicts of Interest: The authors declare no conflict of interest.

\section{References}

1. Stephenson, M.L.; Zamecnik, P.C. Inhibition of Rous sarcoma viral RNA translation by a specific oligodeoxyribonucleotide. Proc. Natl. Acad. Sci. USA 1978, 75, 285-288. [CrossRef] [PubMed]

2. Watts, J.; Deleavey, G.; Damha, M. Chemically modified siRNA: tools and applications. Drug Discov. Today 2008, 13, 842-855. [CrossRef] [PubMed]

3. Keefe, A.D.; Pai, S.; Ellington, A. Aptamers as therapeutics. Nat. Rev. Drug Discov. 2010, 9, 537-550. [CrossRef] [PubMed]

4. Mulhbacher, J.; St-Pierre, P.; Lafontaine, D.A. Therapeutic applications of ribozymes and riboswitches. Curr. Opin. Pharmacol. 2010, 10, 551-556. [CrossRef] [PubMed]

5. Niks, E.H.; Aartsma-Rus, A. Exon-skipping: A first in class strategy for Duchenne muscular dystrophy. Expert Opin. Biol. Ther. 2017, 17, 225-236. [CrossRef] [PubMed]

6. Chiu, Y.-L. siRNA function in RNAi: A chemical modification analysis. RNA 2003, 9, 1034-1048. [CrossRef] [PubMed]

7. Terrazas, M.; Alagia, A.; Faustino, I.; Orozco, M.; Eritja, R. Functionalization of the $3^{\prime}$-ends of DNA and RNA strands with $\mathrm{N}$-ethyl- $\mathrm{N}$-coupled nucleosides: A promising approach to avoid $3^{\prime}$-exonuclease-catalyzed hydrolysis of therapeutic oligonucleotides. Chem. Biol. Chem. 2013, 14, 510-520. [CrossRef] [PubMed]

8. Geary, R.; Tillman, L.; Hardee, G. Routes and formulations for delivery of antisense oligonucleotides. In Antisense Drug Technology; CRC Press: Boca Raton, FL, USA, 2007; pp. 217-236. 
9. Felgner, P.L.; Gadek, T.R.; Holm, M.; Roman, R.; Chan, H.W.; Wenz, M.; Northrop, J.P.; Ringold, G.M.; Danielsen, M. Lipofection: A highly efficient, lipid-mediated DNA-transfection procedure. Proc. Natl. Acad. Sci. USA 1987, 84, 7413-7417. [CrossRef] [PubMed]

10. Azzam, T.; Domb, A. Current developments in gene transfection agents. Curr. Drug Deliv. 2004, 1, $165-193$. [CrossRef] [PubMed]

11. Grijalvo, S.; Alagia, A.; Puras, G.; Zárate, J.; Pedraz, J.L.; Eritja, R. Cationic vesicles based on non-ionic surfactant and synthetic aminolipids mediate delivery of antisense oligonucleotides into mammalian cells. Colloids Surf. B Biointerfaces 2014, 119, 30-37. [CrossRef] [PubMed]

12. Audouy, S.; Molema, G.; de Leij, L.; Hoekstra, D. Serum as a modulator of lipoplex-mediated gene transfection: Dependence of amphiphile, cell type and complex stability. J. Gene Med. 2000, 2, 465-476. [CrossRef]

13. Lv, H.; Zhang, S.; Wang, B.; Cui, S.; Yan, J. Toxicity of cationic lipids and cationic polymers in gene delivery. J. Control Release 2006, 114, 100-109. [CrossRef] [PubMed]

14. Zhang, P.; Wagner, E. History of polymeric gene delivery systems. Top. Curr. Chem. 2017, 26, 375-414. [CrossRef] [PubMed]

15. Punyani, S.; Singh, H. Preparation of iodine containing quaternary amine methacrylate copolymers and their contact killing antimicrobial properties. J. Appl. Polym. Sci. 2006, 102, 1038-1044. [CrossRef]

16. Zelikin, A.N.; Putnam, D.; Shastri, P.; Langer, R.; Izumrudov, V.A. Aliphatic ionenes as gene delivery agents: Elucidation of structure-function relationship through modification of charge density and polymer length. Bioconjug. Chem. 2002, 13, 548-553. [CrossRef] [PubMed]

17. Laschewsky, A. Recent trends in the synthesis of polyelectrolytes. Curr. Opin. Colloid Interface Sci. 2012, 17, 56-63. [CrossRef]

18. Williams, S.R.; Long, T.E. Recent advances in the synthesis and structure-Property relationships of ammonium ionenes. Prog. Polym. Sci. 2009, 34, 762-782. [CrossRef]

19. Bachl, J.; Zanuy, D.; López-Pérez, D.E.; Revilla-López, G.; Cativiela, C.; Alemán, C.; Díaz, D.D. Synergistic computational-experimental approach to improve ionene polymer-based functional hydrogels. Adv. Funct. Mater. 2014, 24, 4893-4904. [CrossRef]

20. Dragan, E.S.; Mayr, J.; Häring, M.; Cocarta, A.I.; Díaz, D.D. Spectroscopic characterization of azo dyes aggregation induced by DABCO-based ionene polymers and dye removal efficiency as a function of ionene structure. ACS Appl. Mater. Interfaces 2016, 8, 30908-30919. [CrossRef] [PubMed]

21. Tiffner, M.; Zielke, K.; Mayr, J.; Häring, M.; Díaz, D.D.; Waser, M. Phase-transfer catalysis with ionene polymers. Chem. Sel. 2016, 1, 4030-4033. [CrossRef]

22. Yudovin-Farber, I.; Yanay, C.; Azzam, T.; Linial, M.; Domb, A.J. Quaternary ammonium polysaccharides for gene delivery. Bioconjugate Chem. 2005, 16, 1196-1203. [CrossRef] [PubMed]

23. San Juan, A.; Letourneur, D.; Izumrudov, V.A. Quaternized poly(4-vinylpyridine)s as model gene delivery polycations: Structure-function study by modification of side chain hydrophobicity and degree of alkylation. Bioconjugate Chem. 2007, 18, 922-928. [CrossRef] [PubMed]

24. Reineke, T.M.; Davis, M.E. The effects of charge separation in quaternary ammonium, DABCO-containing polymers on in vitro toxicity and gene delivery. Mat. Res. Soc. Symp. Proc. 2002, 724, 209-214.

25. Wheeler, C.J. Complex Cationic Lipids Having Quaternary Nitrogen Therein. U.S. Patent 6670332 B1, 30 December 2003.

26. Jorge, A.F.; Dias, R.S.; Pereira, J.C.; Pais, A.A. DNA condensation by pH-responsive polycations. Biomacromolecules 2010, 11, 2399-2406. [CrossRef] [PubMed]

27. Mezei, A.; Pons, R. Release of DNA and surfactant from gel particles: The receptor solution effect and the dehydration aspects. Colloids Surf. B Biointerfaces 2014, 123, 279-285. [CrossRef] [PubMed]

28. Leal, C.; Wadsö, L.; Olofsson, G.; Miguel, M.; Wennerström, H. The hydration of a DNA-amphiphile complex. J. Phys. Chem. B 2004, 108, 3044-3050. [CrossRef]

29. Mezei, A.; Pons, R.; Morán, M.C. The nanostructure of surfactant-DNA complexes with different arrangements. Colloids Surf. B Biointerfaces 2013, 111, 663-671. [CrossRef] [PubMed]

30. Mandelkern, M.; Elias, J.G.; Eden, D.; Crothers, D.M. The dimensions of DNA in solution. J. Mol. Biol. 1981, 152, 153-161. [CrossRef]

31. Mosmann, T. Rapid colorimetric assay for cellular growth and survival: Application to proliferation and cytotoxic assays. J. Immunol. Methods 1983, 65, 55-63. [CrossRef] 
32. Xiong, F.; Mi, Z.; Gu, N. Cationic liposomes as gene delivery system: Transfection efficiency and new application. Pharmazie 2011, 66, 158-164. [PubMed]

33. Rehman, Z.; Hoekstra, D.; Zuhorn, I.S. Mechanism of polyplex and lipoplex-mediated delivery of nucleic acids: Real-time visualization of transient membrane destabilization without endosomal lysis. ACS Nano 2013, 7, 3767-3777. [CrossRef] [PubMed]

34. Grijalvo, S.; Eritja, R. Synthesis and in vitro inhibition properties of oligonucleotide conjugates carrying amphipathic proline-rich peptide derivatives of the sweet arrow peptide (SAP). Mol. Div. 2012, 16, 307-317. [CrossRef] [PubMed]

35. Fornaguera, C.; Grijalvo, S.; Galán, M.; Fuentes-Paniagua, E.; de la Mata, F.J.; Gómez, R.; Eritja, R.; Calderó, G.; Solans, C. Novel non-viral gene delivery systems composed of carbosilane dendron functionalized nanoparticles prepared from nano-emulsions as non-viral carriers for antisense oligonucleotides. Int. J. Pharm. 2015, 478, 113-123. [CrossRef] [PubMed]

36. Mayr, J.; Bachl, J.; Schlossmann, J.; Díaz, D.D. Antimicrobial and hemolytic studies of a series of polycations bearing quaternary ammonium moieties: Structural and topological effects. Int. J. Mol. Sci. 2017, 18, 303. [CrossRef] [PubMed]

37. Metwally, A.A.; Pourzand, C.; Blagbrough, I.S. Efficient gene silencing by self-assempled complexes of siRNA and symmetrical fatty acid amides of spermine. Pharmaceutics 2011, 3, 125-140. [CrossRef] [PubMed]

(C) 2017 by the authors. Licensee MDPI, Basel, Switzerland. This article is an open access article distributed under the terms and conditions of the Creative Commons Attribution (CC BY) license (http://creativecommons.org/licenses/by/4.0/). 